\title{
ANALISIS KETERCAPAIAN STANDAR ISI PADA SEKOLAH DASAR (SD.S Plus Syania Kec. Cimanggung Kab. Sumedang Jawa Barat)
}

\section{Ani Jailani}

Program Pascasarjana UIN Sunan Gunung Djati Bandung Anijailani06@gmail.com

\section{Chaerul Rochman}

Program Pascasarjana UIN Sunan Gunung Djati Bandung chaerulrochman99@uinsgd.ac.id

\section{Nina Nurmila}

Program Pascasarjana UIN Sunan Gunung Djati Bandung

\begin{abstract}
Abstrak
Setiap lembaga penyelenggara pendidikan formal wajib mengimplementasikan delapan standar tersebut didalam pelaksanaan pendidikan. Seperti halnya pada Sekolah Dasar SD.S Plus Syania yang menjadi objek penelitian, dimana penelitain ini bertujuan untuk mengkaji tentang penerapan Standar Isi yang dilaksanakan pada sekolah tersebut.Dari data yang diperolah Implementasi Standar Isi di Sekolah ini memenuhi standar nasional, sehingga pada setandar ini bisa dikatan baik dan sangan menunjang untuk proses pembelajaran yang lebih baik. Itu bisa dilihat dari kesimpulan pengamatan sebagai berikut; Profil pencaipaian pada indikator Standar Isi memperoleh hasil sebanyak 90\% dengan rincian sebagai berikut : 1) Indikator yang medapatkan penilain A sebanyak $80 \%$ dengan perolehan scor 80,2 ) indikator yang memperoleh Nilai B sebanyak $5 \%$ dengan perolehan scor 10 dan 3) indikator yang mendapatkan penilain E sebanyak 5\% dengan perolehan scor 5. Dari data diatas indikator yang belum mencapai scor maksimal dan paling rendah adalah pada indikator 6 , dimana sekolah belum mampu mengimplementasikan pembelajaran berbasis tematik terpadu dan sebagian besar masih menggunakan Kurikulum KTSP.
\end{abstract}

Kata- kata kunci: standar nasional pendidikan, capaian standar isi dan pendekatan pembelajaran tematik terpadu

\section{Abstract}

In Government Regulation No.19 of 2005 concerning National Education Standards the government formulates Standard standards in the formulation of National Education Standards to improve the quality of education as well as efforts to achieve national education goals in accordance with content standards, process standards, competition standards, educator standards and education staff , standards for facilities and infrastructure, management standards, funding standards, and education calculation standards. For this reason, every formal education institution must implement these standards in the implementation of education. Like challenging at SD Plus Syania Elementary School which is the object of research, where this research aims to examine the application of the Content Standards implemented at the school. From the data obtained, the 74

JP: Jurnal Ilmiah PGMI, Volume 5 No. 1, Juni 2019 Available Online at http:/jurnal.radenfatah.ac.id/index.php/jip/ 
Implementation of Standard Content in the School meets national standards, made on this standard can be good and supports the better learning process. That can be seen from the conclusion of the observation as; The scoring profile on the Standard Content indicator gets results as much as $90 \%$ with the following details: 1) Indicators that get A assessment as much as $80 \%$ by agreeing to a score of 80,2) indicators that get $B$ Value of 5\% with scor conditions 10 and 3) indicators get E assessment of 5\% by agreeing to score 5. From the data obtained by indicators that have not reached the maximum and lowest scores on indicator 6, where schools have not been able to support integrated thematic based learning and most still use the KTSP Curriculum.

Keywords: National Education Standards, Achievement of the Content Standards and integrated thematic learning approach

\section{PENDAHULUAN}

Pendidikan nasional yang diimplementasikan di Indonesia memiliki fungsi dan merujuk kepada falsafah Negara yakni Pancasila dan Undang-undang Republik Indonesia (UUD 19945) yang memiliki fungsi untuk dan tujuan membentuk peradaban bangsa Indonesia.Dengan demikian pendidikan nasional harus mampu memeratakan kesempatan pendidikan, peningkatan mutu dan relevansi serta efisiensi manajemen pendidikan.

Pemerataan yang dimaksud adalah belajar 9 tahun. Terkait dengan pembahawasan tentang Standar Pendidikan, banyak para pakar pendidikan yang mejelaskan sepertihalnya yang Dikemukakan oleh Sudrajat (2010), bahwa Standar Nasional Pendidikan memiliki fungsi sebagai dasar dalam perencanaan, pelaksanaan, dan pengawasan pendidikan dalam rangka mewujudkan pendidikan nasional.

Dapat kita artikan bahwa Standar Pendidikan adalah sebuah dasar atau pondasi utama dalam mengimplementasikan pendidikan untuk mewujudkan tujuan pendidikan yang dirumuskan dan tercantum didalam Undang-Undang. Standar tersebut menjadi tolak ukur dari setiap satuan pendidikan dalam merencanakan melaksanakan, mengelola, dan mengevaluasi proses pendidikan yang dilakukan.

Standar nasional pendidikan merupakan standar sekolah dalam melaksanakan proses pendidikan sebagai jaminan mutu pendidikan yang dilaksanakan oleh sekolah. Standar nasional ini menjadi komponen yang sangat

JIP: Jurnal Ilmiah PGMI, Volume 5 No. 1, Juni 2019

Available Online at http:/jurnal.radenfatah.ac.id/index.php/jip/ 
penting dalam pembelajaran, terutama di tingkat dasar. Karenanya, berdasarkan latar belakang di atas, peneliti tertarik untuk meneliti tentang ketercapaian standar di SD.S Plus Syania Kec. Cimanggung Kab. Sumedang Jawa Barat.

\section{METODE PENELITIAN}

Penelitian ini menggunakan metode penelitian kualitatif dengan pendekatakan deskriptif analisis. Teknik pengumpulan data menggunakan wawancara, observasi, dan dokumentasi. Analisis datanya meliputi reduksi data, penyajian data, dan verifikasi data atau penarikan kesimpulan. Keabsahan datanya dilakukan uji kredibilitas, dependabilitas, transfermabilitas, dan konfirmabilitas.

\section{PEMBAHASAN}

Berdasakan hasil perolehan dan analisis data tentang ketercapaian indicator pada standar Isi pada SD.S Plus Syania Kec. Cimanggung Kab. Sumedang Jawabarat maka dapat dijelaskan terkait dengan profil ketercapaian, Komposisi indicator berdasarkan kualifikasi capaian standar dan alternative pemecahan masalah sebagai berikut.

\section{ProfilKetercapaianIndikatorStandar Isi}

ProfilketercapaianstandarIsidapatditunjukkanmelakuigrafik 1 berikut.

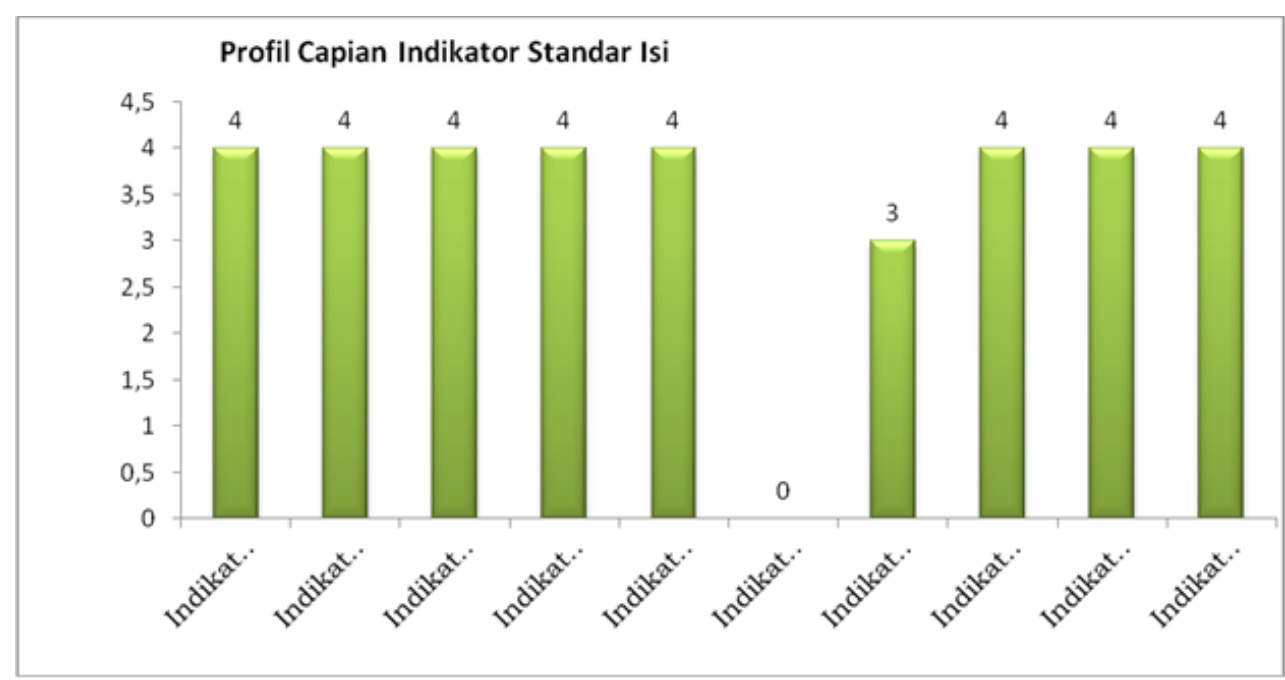

Gambar 1. Profil Capaian Indikator Standar Isi 
Grafik di atas menunjukanprofil yang menjukancapaianindikatorStandar Isi SD.S Plus Syania Kec. Cimanggung Kab. Sumedang Jawa Barat. Mengacu pada aturan dalam penentuan Nialai Akhir Akreditasi, untuk mengkonversikan setiap Opsi jawaban A, B, C, D atau E kedalam skor setiap butirnya dimana setiap butir pernyataan instrumen yang dijawab diberikan sekor sebagai Berikut :

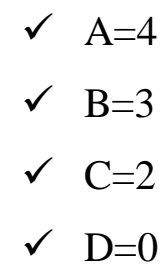

Dari 10 Indikator pada Standar Isi tingkat sekolah Dasar, sejauh ini dari data yang diperoleh di lapangan sebanyak80\% indikator yang mendapatkan penilaian baik dari setiap masing-masing indikator, hanya saja pada beberapa indikator yang mendapatkan penilaian lebih kecil, seperti halnya pada indikator 6 . Perolehan nilai dari indikator 6 yaitu E dengan indikator 0, pada indikator 6 ini memuat poin tentang pengembangan pembelajaran tematik terpadu yang sesuai dengan tingkat kompetensi dan ruang lingkup materi pembelajaran setiap kelas. Dari hasil observasidata yang ditemukan dari jumlah 12 Pendidik hanya berjumlah 3 orang Guru saja atau 27\% saja Guru yang sudah mengembangkan perangkat pembelajaran tematik terpadu berdasarkan tingkat kompentensi dan ruang lingkup materi pembelajaran di setiap kelas, dikarekan pada tahun Ajaran 2018/2019 hanya baru 2 kelas saja yang sudah menerapkan Kurikulum 2013, hal ini dilakukan secara bertahap.

Selanjutnya pada indikator 7 dalam pengembangan kurikulum, sekolah melaksanakan pengembangan kurikulum hanya melibatkan 3 unsur yakni : Pengawas Sekolah, Komite Sekolah dan Penyelenggara Sekolah. Sejauh ini sekolah belum melibatkan narasumber dalam pengembangan kurikulum yang diterapkan disekolah. Sehingga dari hasil analisis secara keseluruhan dapat diketahui bahwa pencapaian pada Standar Isi di SD.S Plus Syania Kel. Cihanjuang Kec. Cimanggung Kab. Semedang adalah 70\%. 
Berdasarkan analisis data diatas dapat kita ketahui bahwa indikator yang belum memperoleh skor maksimal pada standar isi disekolah SDS Plus Syania adalah pada implementasi pengembangan perangkat pembelajaran tematik terpadu berdasarkan tingkat kompentensi dan ruang lingkup materi pembelajaran pada setiap kelas. Implementasi pembelajaran tematik terpadu sangat baik untuk dilaksanakan, mengingat konsep pembelajaran tematik terpadu ini termuat didalam Kurikulum 2013 yang sedang di upayakan penerapannya disetiap masing-masing satuan pendidikan. Seperti halnya yang yang di ungkapkan oleh Min, K.C., Rashid, A.M. and Nazri, M.I., (2012) memberikan pernyataan bahwa Ada hubungan yang signifikan antara guru tingkat pemahaman terhadap pendekatan tematik dengan praktik konstan guru. Temuan lain juga menunjukkan pengalaman guru dalam mengajar tidak jauh berbeda dari praktik pendekatakan tematik mereka. Pursitasari, I.D et al (2015) dari hasil penelitannya Studi tersebut mengungkapkan bahwa sains terintegrasi berbasis tematik belajar dapat meningkatkan keterampilan berpikir kritis dan karakter siswa SMP kelas tujuhdengan kategori baik. Setiawan, A et al (2018) Hasil evaluasi keseluruhan menunjukkan bahwa pembelajaran tematik yang dilakukan oleh guru itu baik.

\section{AnalisisKesulitanKetercapaianStandar Isi}

Adapunkesulitan, analisis, dan alternatif pemecahanmasalahketercapaian indikator padastandarisidapatditunjukkandengantabel 1 berikut.

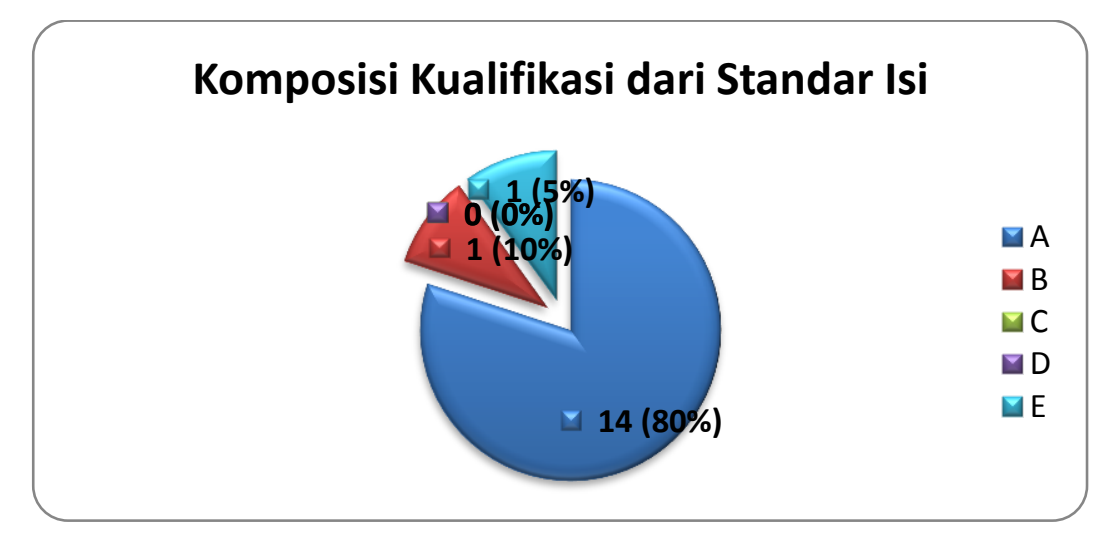

Gambar 2 Komposisiindikator berdasarkanKualifikasicapaiandariStandarIsi

78

JP: Jurnal Ilmiah PGMI, Volume 5 No. 1, Juni 2019

Available Online at http:/jurnal.radenfatah.ac.id/index.php/jip/ 
Gambar tersebut memberikan informasi fakta ditempat penelitian, bawah nunjukan dari hasil temuan dilapangan ada beberapa permasalahan pada indikator standar Isi yang mendapatkan skor penilaian 3 dan 0 . Seperti halnya pada indikator 6 dimaa sekolah baru mampu mengimplementasikan Kurikulum 2013 pada 2 kelas saja ditahun pelajaran 2018/2019, yakni pada kels 1 (satu) dan Kelas IV (Empat), sementara untuk kelas yang lainnya masih menggunakan Kurikulum Tingkat Satuan Pendidikan (KTSP). Sehingga dalam pelaksanaanya dari jumlah total pendidik yang berjumlah 12 Orang hanya baru sebanyak 3 Orang Guru atau $27 \%$ yang sudah mengimplementasikan pengembangan pembelajaran berbasis tematik terpadu sesuai tingkat kopentsi dan ruang lingkup materi pembelajaran pada setiap kelas. Dalam rangka pemenuhan indikator 6, hal ini sekolah berupaya untuk mengimplementasikan Kurikulum 2013 pada tahun Pelajaran 2019/2020 yang akandatang pada semua kelas.

Selain pada indikator 6, kekuranganpun terlihat pada indikator 7 dimana Kepala sekolah/ madrasah bersama guru mengembangkan kurikulum sesuai dengan pedoman pengembangan KTSP dengan melibatkan 4 unsur yakni:

1) Pengawas sekolah/madrasah

2) Narasumber

3) Komite sekolah/madrasah

4) Penyelenggara lembaga pendidikan

Berdasarkan dari data yang ditemukan dilapangan, sekolah hanya melibatkan 3 unsur dalam penyususnan kurikulum dan tidak melibatkan unsur kedua yaitu melibatkan Narasumber dalam penyusunan kurikulum yang jadi acuan di sekolah SD.S Plus syania.

Data hasil temuan dilapangan mengungkapkan bahwa Kesulitan yang di yang dilami untuk ketercapaian pada beberapa indikator yang belum memenuhi scor maksimum pada Standar Isi sebagai berikut : 


\section{Indikator 6}

Responden Ibu Awang Andayani,S.Pd

\begin{tabular}{|c|c|c|}
\hline Masalah & $\begin{array}{c}\text { Rekaman Wawancara } \\
\text { (Triangulasi) }\end{array}$ & Solusi \\
\hline $\begin{array}{l}\text { Sekolah Baru } \\
\text { melaksanakan } \\
\text { Kurikulum } 2013 \\
\text { pada dua kelas saja } \\
\text { yakni Kelas } 1 \text { dan } \\
4 .\end{array}$ & $\begin{array}{l}\text { "Sekolah Baru melaksanakan } \\
\text { tematik terpadu pada kelas } 1 \text { dan } 4 \\
\text { saja, dan untuk kelas yang lain } \\
\text { masih menggunakan Kurikulum } \\
\text { KTSP" }\end{array}$ & $\begin{array}{l}\text { Harapannya untuk } \\
\text { diberikannya pelatihan } \\
\text { (diklat) kepada Guru Wali } \\
\text { Kelas untuk mendukung } \\
\text { pengembangan perangkat } \\
\text { pembelajaran } \\
\text { tematik terpadu berbasis }\end{array}$ \\
\hline
\end{tabular}

\section{Indikator 7}

Responden : Bpk Suparman Sidiq

\begin{tabular}{|c|c|c|}
\hline Masalah & $\begin{array}{c}\text { Rekaman Wawancara } \\
\text { (Triangulasi) }\end{array}$ & Solusi \\
\hline $\begin{array}{l}\text { Sekolah Baru } \\
\text { memenuhi } 3 \text { Unsur } \\
\text { dalam } \\
\text { pengembangan } \\
\text { Kurikulum. }\end{array}$ & 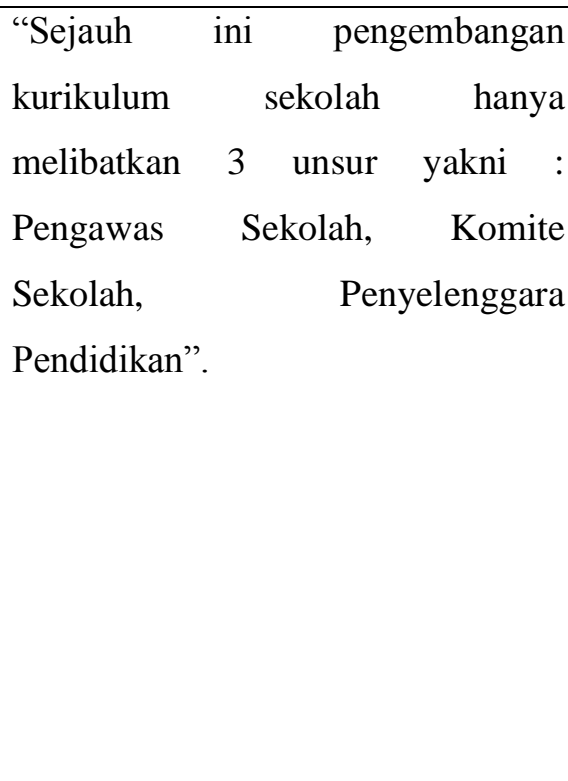 & $\begin{array}{l}\text { Harapannya sekolah untuk } \\
\text { kedepannya } \\
\text { melibatkan } \\
\text { dalam } \\
\text { Kurikulum agar benyusunan } \\
\text { memberikan masukan atau } \\
\text { pengetahuan baru kepada } \\
\text { para dewan gurudan } \\
\text { pengelola pendidikan } \\
\text { dalam mengambangkan } \\
\text { kurikulum dengan baik dan } \\
\text { sesuai dengan kebutuhan. }\end{array}$ \\
\hline
\end{tabular}




\section{Analisis Pembahasan}

Upaya pengembangannya menurut para pakar meliputi point-poin landasan konseptual, empiris, dan prinsip serta karakteristik pengembangan kurikulum tersebut, seperti halnya didalam pengembangan Kurikulum 2013 yang memiliki karakteristik sebagai berikut (Kunandar, 2013:24-25; Prastowo, 2015:6-7). Mengembangkan keseimbangan antara pengembangan sikap spiritual dan sosial, rasa ingin tahu, kreativitas, kerjasama dengan kemampuan intelektual dan psikomotorik.

Sekolah adalah bagian yang penting kehidupan masyarakat sebagai sarana untuk belajar, di dalamnya siswa akan dilatih untuk belajar sikap, pengetahuan, dan keterampilan serta menerapkannya dalam berbagai situasi di sekolah dan masyarakat.

Kompetensi dikembangkan untuk memperkuat (reinforced) dan memperkaya (enriched) antarmata pelajaran dan jenjang pendidikan (organisasi horizontal dan vertikal). Mengingat pentingnya pengembangan kurikulum, sekolah mesti melakukan proses ini bersama timpengembang kurikulum sebagai upaya untuk menciptakan kualitas pendidikan dilembaga pendidikan tersebut, seperti halnya yang termuat didalam Indikator 7 didalam penilain Standar Isi.

Standar nasional pendidikan bertujuan untuk memacu pengelola, penyelenggara, dan satuan pendidikan sebagai perangkat untuk mendorong terwujudnya transparansi dan akuntabilitas publik dalam penyelenggaraan sistem pendidikan nasional.Dalam pembahasana ini Observasi dilakukan fokus pada Standar Isi.

Dalam implementasinya didalam Pendidikan Standar isi itu mencakup ruang lingkup materi pembelajaran dan tingkat kompetensinya untuk mencapat jenjang tertentu. SI memuat kerangka dasar struktur kurikulum, beban belajar, kurikulum tingkat satuan pendidikan, kalender akademik. Kurikulum pendidikan dapat digolongkan pada yaitu isi (content) dan proses (Tuckman, p. 228).

Dalam mengimplementasikan Standar Nasional Pendidikan tersebut diatas terutama implementasi standari isi di SD.S Plus Syania, sejauh ini sekolah sudah

JIP: Jurnal Ilmiah PGMI, Volume 5 No. 1, Juni 2019 
menjalankan tugasnya yang termuat didalam indikator standar isi, terlihat dari perolehan data dari data di lapangan utuk periode tahun ajaran 2018/2019 memperoleh $70 \%$ atau dengan jumlah Nilai 80 dari total penilaian dari semua indikator. Dari hasil temuan data dilapang, peneliti melihat masih terdapat kekurangan di beberapa indikator yang belum bisa terpenuhi atau dilaksanakan didalam proses pendidikan di SD.S Plus Syania yang akan menjadi bahan pertimbangan perbaikan untuk menyempurnakan dan perbaikan demi mewujudkan tercapainya tujuan pendidikan Nasional.

\section{SIMPULAN}

Dari hasil observasi dan analisis data yang ditemukan dilapangan, pada penelitian ini bisa di simpulkan bahwa jika merujuk data yang ada bahawa ketercapain Standar Isi dari Standar Pendidikan Nasioanal yang di Implementasikan di Sekolah SD.S Plus Syania masih terbilang Rendah. Dari hasil analisis menunjukan perolehan sebesar $70 \%$.

Kekurangan yang sangat rendah itu terlihat pada indikator ke 6 dimana sekolah belum memaksimalkan dalam pengimplementasian pengembangan pembelajaran tematik terpadu sesuai tingkat kopentsi dan ruang lingkup materi pembelajaran pada setiap kelas, padahal jika kita merujuk kepada penelitan sebelumnya bahwa pengembangan pembelajaran tematik itu sangat baik jika di implementasikan, terlebih lagi model pembelajaran ini sudah di adopsi dan menjadi rancangan pembelajaran didalam Kurikulum yang kembangkan sekarang yakni K-13. Akan tetapi sekolah masih bertahap dalam peralihanya kepada Kurikulam 2013.Selain itu, masih sedikit guru yang sudah pernah mengikuti diklat pelatihan Implementasi Kurikulum 2013. 


\section{DAFTAR RUJUKAN}

Min, K.C., Rashid, A.M. and Nazri, M.I., 2012. Teachers' understanding and practice towards thematic approach in teaching integrated living skills (ILS) in Malaysia. International Journal of Humanities and Social Science, 2(23), pp.273-281.

Pursitasari, I.D., Nuryanti, S. and Rede, A., 2015. Promoting of Thematic-Based Integrated Science Learning on the Junior High School. Journal of Education and Practice, 6(20), pp.97-101.

Setiawan, A., Pusporini, W., Nartani, C.I. and Hamidah, N., 2018, November. Evaluation Of Thematic Learning In 2013 Curriculum In SD. In PROCEEDING INTERNATIONAL SEMINAR ON EDUCATION MANAGEMENT.

PRISMA PERMANA, D. A. N. I. (2015). Analisis Kelayakan Standar Isi, Standar Proses, Dan Standarpembiayaan Pendidikan Mengacu Pada Standar Nasional Pendidikan Dismk Negeri Se-Kota Madya Surabaya. Jurnal Pendidikan Teknik Mesin, 3(02).

Raharjo, S. B. (2014). Kontribusi Delapan Standar Nasional Pendidikan terhadap Pencapaian Prestasi Belajar. Jurnal Pendidikan dan Kebudayaan, 20(4), 470-482.

DH, I. K. (2011). Evaluasi Program SMP Standar Nasional Berdasarkan Standar Nasional Pendidikan. Jurnal Pendidikan dan Kebudayaan, 17(6), 619-634.

Rembang, P., Hatidja, D., \& Komalig, H. (2017). Deskripsi SMA/SMK Di Kabupaten Minahasa Tenggara Berdasarkan Indikator Standar Nasional Pendidikan Berbasis Evaluasi Diri Sekolah (Standar Sarana Dan Prasarana, Standar Pengelolaan, Standar Pembiayaan Pendidikan Dan Standar Penilaian Pendidikan). Jurnal Ilmiah Sains, 17(2), 117-125.

Purnomo, A. R. (2016). Analisi Pemenuhan Standar Nasional Pendidikan (SNP) DI SMP N 4 PRAMBANAN. Hanata Widya, 5(6).

Sunan, A. P. U. I. N. Transformasi kurikulum pendidikan dasar dan menengah di indonesia.

JIP: Jurnal Ilmiah PGMI, Volume 5 No. 1, Juni 2019

Available Online at http://jurnal.radenfatah.ac.id/index.php/jip/ 